\title{
Pengaruh Audit Tenure, Rotasi Audit Dan Ukuran Kantor Akuntan Publik (KAP) Terhadap Kualitas Audit
}

\author{
${ }^{1}$ Carolus Askikarno Palalangan \\ 2Johannes Baptista Halik \\ ${ }^{3}$ Maria Yessica Halik \\ ${ }^{1}$ carolus@ukipaulus.ac.id \\ 1,2,3 Program Studi Akuntansi, Fakultas Ekonomi dan Bisnis, Universitas Kristen Indonesia Paulus
}

\begin{abstract}
Abstrak Tujuan dari penelitian ini adalah untuk menguji pengaruh audit tenure, rotasi audit, ukuran kantor akuntan publik dan kualitas audit pada perusahaan sektor perdagangan besar. Audit tenure, rotasi audit dan ukuran kantor akuntan publik sebagai variabel independen. Kualitas audit sebagai variabel dependen. Penelitian ini menggunakan teori dasar yaitu teori keagenan. Penelitian ini menggunakan data sekunder yang diperoleh dari Bursa Efek Indonesia (BEI) selama periode 2013-2017. Proses pengambilan sampel dilakukan dengan menggunakan metode purposive sampling dan penelitian ini menggunakan 100 observasi. Metode analisis untuk menguji hipotesis adalah analisis regresi logistik. Hasilnya menunjukkan bahwa (1) audit tenure berpengaruh negatif terhadap kualitas audit. (2) rotasi audit tidak berpengaruh terhadap kualitas audit, (3) ukuran kantor akuntan publik tidak berpengaruh terhadap kualitas audit.
\end{abstract}

Kata Kunci: audit tenure, rotasi audit, ukuran KAP, kualitas audit

Abstract The purpose of this study was to examine the effect of audit tenure, audit rotation, size of the public accounting firm and audit quality on large trading sector companies. Audit tenure, audit rotation and the size of the public accounting firm as an independent variable. Audit quality as the dependent variable. This study uses the basic theory of agency theory. This study uses secondary data obtained from the Indonesia Stock Exchange (IDX) during the period 2013-2017. The sampling process was carried out using the purposive sampling method and this study used 100 observations. The analytical method for testing hypotheses is logistic regression analysis. The results show that (1) audit tenure has a negative effect on audit quality. (2) audit rotation does not affect audit quality, (3) the size of the public accounting firm does not affect audit quality.

Keywords: audit tenure, audit rotation, size of the public accounting firm, audit quality

\section{Pendahuluan}

Pada era globalisasi saat ini perkembangan dunia bisnis semakin besar dan luas, khususnya dalam lingkup bisnis jasa akuntan publik yang semakin meningkat seiring banyaknya perusahaan yang membutuhkan jasa audit laporan keuangan. Laporan keuangan merupakan catatan informasi keuangan perusahaan yang menggambarkan kinerja perusahaan tersebut, sehingga kewajaran suatu laporan keuangan sangat diperlukan bagi para pengguna laporan keuangan dalam 
pengambilan keputusan. Dalam menilai kewajaran suatu laporan keuangan yang disajikan oleh perusahaan, diperlukan suatu proses untuk memperoleh serta mengevaluasi laporan keuangan secara objektif yaitu melalui proses audit. Laporan keuangan yang telah diaudit dapat memberikan jaminan yang tinggi akan kewajaran laporan keuangan dibandingkan laporan keuangan yang tidak diaudit. Oleh karena itu auditor sebagai pelaku audit harus profesional dalam mengaudit laporan keuangan sehingga audit laporan keuangan memiliki kualitas yang dapat dipercaya oleh pihak internal dan eksternal perusahaan serta memperoleh kepercayaan dalam menjalankan bisnis jasa akuntan publik sehingga auditor dapat bertahan dan meningkatkan eksistensinya dalam dunia bisnis.

Dalam mempertahankan eksistensi auditor dan untuk bertahan ditengah persaingan yang ketat, khususnya dibidang bisnis pelayanan jasa akuntan publik harus dapat menghimpun klien sebanyak mungkin dan mendapatkan kepercayaan dari masyarakat luas, oleh karena itu menuntut para auditor tetap memiliki kualitas audit yang baik (Putra, 2013)

Kualitas audit adalah suatu nilai yang didapatkan atau hasil yang diperoleh dari proses audit yang berpedoman pada standar auditing dan prosedur audit yang telah ditetapkan yang menjadi pedoman pelaksanaan tugas dan tanggung jawab profesi seorang auditor. Kualitas audit berhubungan dengan seberapa baik sebuah pekerjaan diselesaikan dibandingkan dengan standar yang telah ditetapkan. Dengan mengaudit laporan keuangan klien, auditor dapat menemukan pelanggaran yang terjadi dalam sistem akuntansi klien dan melaporkannya dalam laporan keuangan auditan, dimana dalam melaksanakan tugasnya tersebut auditor berpedoman pada standar auditing dan kode etik akuntan publik. Kualitas audit yang ditetapkan auditor digunakan untuk meningkatkan kepercayaan laporan keuangan pengguna informasi akuntansi sehingga dapat mengurangi risiko informasi yang tidak kredibel bagi pengguna laporan keuangan.

Namun pada saat ini kepercayaan akan auditor semakin menurun dikarenakan banyaknya kasus yang melibatkan auditor itu sendiri seperti yang terjadi pada kantor akuntan publik mitra Ernest \& Young (EY) di Indonesia yakni KAP Purwantono, Suherman \& Surya yang sepakat membayar denda senilai US\$ 1 juta (sekitas Rp 13,3 Miliar) kepada regulator Amerika Serikat akibat divonis gagal melakukan audit laporan keuangan kliennya. Kesepakatan itu diumumkan Badan Pengawas Perusahaan Akuntan Publik AS (Publik Accounting Oversight Board PCAOB) pada Kamis 9 Februari 2017 waktu Washington. Kasus ini merupakan insiden terbaru yang menimpa kantor akuntan publik di negara berkembang yang melanggar kode etik jaringan EY di Indonesia yang mengumumkan hasil audit atas perusahaan telekomunikasi (ISAT) pada 2011 memberikan opini yang didasarkan atas bukti yang tidak memadai.

Temuan itu berawal ketika kantor akuntan mitra EY di AS melakukan kajian atas hasil audit kantor akuntan di Indonesia. Mereka menemukan bahwa hasil audit atas perusahaan telekomunikasi itu tidak didukung oleh data yang akurat yakni 
dalam hal persewaan lebih dari 4 ribu unit tower seluler. Namun afiliasi EY di Indonesia itu merilis laporan hasil audit dengan status wajar tanpa pengecualian.

PCAOB (The Publik Accounting Oversight Board) juga menyatakan tak lama setelah dilakukan pemeriksaan atas audit laporan pada 2012 afiliasi EY di Indonesia menciptakan belasan pekerjaan audit baru yang "tidak benar" sehingga menghambat proses pemeriksaan PCAOB selain mengenakan denda US\$ 1 juta juga memberikan sanksi kepada dua auditor mitra EY yang terlibat dalam audit pada 2011, Roy Imam Wirahardja, senilai US\$ 20.000 dan larangan praktik selama lima tahun, mantan direktur EY Asia-Pasific James Randall Leali didenda US\$ 10.000 dan dilarang berpraktik selama satu tahun.

Berdasarkan kasus KAP mitra EY di Indonesia dapat disimpulkan bahwa auditor dalam melaksanakan tugas dan tanggung jawabnya belum dapat dikatakan sebagai auditor profesional walaupun telah melaksanakan prosedur dan program audit yang benar tetapi belum memiliki sikap independensi yang tinggi yaitu suatu keadaan yang tidak terikat dengan pihak klien.

Seorang auditor dapat meningkatkan sikap profesionalnya dalam melaksanakan audit laporan keuangan dengan berpedoman pada standar audit yang telah ditetapkan oleh Institut Akuntan Publik Indonesia (IAPI) yaitu standar pekerjaan lapangan dan standar pelaporan, seorang auditor juga harus menerapkan dan mematuhi prinsip dasar etika profesional, yaitu prinsip integritas, prinsip objektivitas, prinsip kerahasiaan dan prinsip perilaku profesional (SPAP, 2013).

Sesuai dengan kode etik profesi yang disusun oleh IFRS (International Federation of Accountants) independensi merupakan bagian dari salah satu prinsip fundamental kode etik profesi akuntansi yaitu objektivitas. Dalam kode etik profesi akuntansi, objektivitas merupakan prinsip fundamental yang mensyaratkan seorang auditor untuk tidak bias, bebas dari benturan kepentingan dan pengaruh lainnya yang dapat yang dapat mengesampingkan profesional judgement. Dalam melaksanakan audit, auditor harus memperhatikan dalam hal (1) merencanakan dan merancang pendekatan audit; (2) memperoleh bukti untuk mendukung pengendalian khusus; (3) memperoleh bukti melalui prosedur audit; (4) melaksanakan prosedur analitis substantive; (5) melakukan pengujian rincian saldo; (6) melaksanakan pengujian tambahan untuk penyajian dan pengungkapan; (7) mengumpulkan bukti akhir; (8) mengeluarkan laporan audit (Indarto, 2011).

Untuk menjaga independensi auditor, maka pemerintah mengeluarkan aturan yang mengatur rotasi audit pada 2015 yaitu PP No.20/2015 tentang Praktik Akuntan Publik. Dalam PP No.20/2015 pasal 11 ayat (1) dijelaskan bahwa akuntan publik dalam melakukan audit atas suatu perusahaan berlaku selama 5 tahun buku berturut-turut. Setelah periode cooling-off selesai, maka AP dapat kembali memberikan jasa audit pada perusahaan tersebut. Perusahaan yang dimaksud dalam PP No. 20/2015 adalah industri di sektor pasar modal, bank umum, dana pensiunan perusahaan asuransi/reasuransi atau BUMN, sebagaimana dijelaskan pada pasal 11 ayat (2). Untuk memperketat pengawasan terhadap AP yang melakukan audit terhadap perusahaan penyelenggara jasa keuangan, OJK 
mengeluarkan POJK No. 13 Tahun 2017 tentang Penggunaan Jasa Akuntan Publik Dan Kantor Akuntan Publik Dalam Kegiatan Jasa Keuangan. Dalam peraturan tersebut, bahwa institusi jasa keuangan wajib membatasi penggunaan jasa audit dari AP paling lama 3 tahun buku berturut-turut. Sedangkan pembatasan penggunaan jasa dari KAP tergantung pada hasil evaluasi Komite Audit. Selain itu, institusi jasa keuangan harus menggunakan akuntan publik dan Kantor Akuntan Publik (KAP) yang terdaftar di OJK.

Pada umumnya kualitas audit bukan hanya dipengaruhi oleh faktor internal, tetapi juga faktor eksternal seperti audit tenure, rotasi audit dan ukuran kantor akuntan publik. Audit tenure adalah lamanya hubungan yang terjalin antara auditor dan klien dalam mengaudit laporan keuangan. Menurut Hartadi (2012), audit tenure adalah lamanya waktu auditor tersebut secara berturut-turut telah melakukan pekerjaan audit terhadap suatu perusahaan. Dengan jangka waktu hubungan antara klien dengan auditor maka dapat menimbulkan hubungan yang erat sehingga ada kemungkinan auditor tidak bersikap independen. Dengan panjangnya audit tenure maka untuk mengurangi resiko hilangnya independensi auditor maka dilakukan rotasi audit.

Rotasi audit yaitu pergantian KAP dalam mengaudit laporan keuangan klien. Menurut E Yuvisa I, dkk (2008) yaitu ketika hubungan klien dengan suatu kantor akuntan berlangsung selama bertahun-tahun, klien dapat dipandang sebagai sumber pendapatan bagi kantor akuntan publik secara terus menerus. Namun tidak dapat dipungkiri dengan singkatnya masa perikatan antara audior dengan klien dapat menimbulkan berbagai permasalahan seperti meningkatnya biaya perikatan yang ditanggung oleh perusahaan klien karena dengan cepat menyelesaikan kontrak dengan auditor juga audior akan lama mendalami dan menelusuri laporan keuangan klien karena belum memahami secara luas akan perusahaan klien yang bersangkutan. Oleh karena itu, diberlakukan adanya rotasi yang bersifat mandatory dan valountery kantor akuntan publik supaya mengurangi dan menghindari hubungan spesial yang terjalin antara klien dengan kantor akuntan publik.

Faktor yang ketiga yaitu ukuran kantor akuntan publik, kantor akuntan publik terdiri dari KAP Big Four dan KAP Non Big four. Menurut Sulastono (2016: 33), kualitas auditor yang ada dalam kantor akuntan yang memiliki reputasi big four, dianggap memiliki kecepatan, ketepatan dan memiliki sarana serta prasarana yang lebih baik dari auditor kantor akuntan non big four. Hal ini bertentangan dengan kasus yang terjadi pada KAP Purwantono, Suherman \& Surya yang merupakan mitra Ernest \& Young (EY) salah satu KAP Big Four yang mengaudit laporan keuangan salah satu perusahaan telekomunikasi di Indonesia yang tidak memiliki data yang akurat kemudian memberikan opini wajar tanpa pengecualian sehingga KAP Purwanto, Suherman dan Surya diberikan sanksi berupa denda US\$ 1juta dan larangan melakukan praktik selama satu tahun.

Penelitian ini mereplikasi penelitian terdahulu yaitu penelitian Ramdani (2016) yang meneliti pengaruh fee audit, audit tenure, rotasi audit dan ukuran perusahaan pada perusahaan sektor keuangan yang terdaftar di BEI tahun 2012- 


\section{Jurnal Buana Akuntansi}

2014. Perbedaan penelitian ini dengan penelitian terdahulu yaitu hanya mengambil tiga variabel bebas yaitu audit tenure, rotasi audit dan ukuran kantor akuntan publik selain itu studi empiris dengan perusahaan yang berbeda dalam hal ini menggunakan perusahaan perdagangan besar pada periode yang berbeda yaitu tahun 2013-2017.

Dalam penelitian ini, peneliti memakai studi pada perusahaan perdagangan besar yang terdaftar di Bursa Efek Indonesia dikarenakan perusahaan perdagangan besar memiliki pengaruh yang besar terhadap pertumbuhan ekonomi Indonesia. Berdasarkan uraian di atas, peneliti tertarik dan termotivasi melakukan penelitian untuk mengetahui pengaruh audit tenure, rotasi audit dan ukuran kantor akuntan publik terhadap kualitas audit. Berdasarkan hal tersebut, maka peneliti melakukan penelitian yang berjudul "Pengaruh Audit Tenure, Rotasi Audit dan Ukuran Kantor Akuntan Publik (KAP) terhadap Kualitas Audit".

\section{METODE PENELITIAN}

\section{Populasi Dan Sampel}

Populasi dan sampel penelitian ini adalah perusahaan perdagangan besar yang terdaftar di Bursa Efek Indonesia (BEI) pada periode 2013-2017. Perusahaan perdagangan besar dipilih karena merupakan salah satu sektor yang berpengaruh dalam pertumbuhan ekonomi di Indonesia. Pada penelitian ini, populasi yang digunakan adalah perusahaan perdagangan besar yang terdaftar di Bursa Efek Indonesia (BEI) pada periode 2013 sampai 2017. Jumlah populasi dalam penelitian ini sebanyak 37.

Metode yang digunakan dalam penelitian ini adalah Purposive Sampling, yaitu penetuan sampel dari populasi yang ada berdasarkan kriteria. Berdasarkan metode tersebut, maka kriteria yang ditetapkan untuk penentuan sampel dalam penelitian ini adalah sebagai berikut:

1. Perusahaan perdagangan besar yang terdaftar di Bursa Efek Indonesia (BEI) selama tahun 2013-2017.

2. Perusahaan perdagangan besar yang menyediakan laporan keuangan, annual report dan laporan yang telah diaudit oleh auditor independen selama tahun 2013-2017.

3. Sektor keuangan yang selama tahun 2013-2017 tidak mengalami delisting dari Bursa Efek Indonesia.

Berdasarkan kriteria tersebut, maka penelitian memperoleh sampel sebanyak 20 perusahaan perdagangan besar yang menjadi sampel penelitian adalah 100 unit yaitu 20 perusahaan $x 5$ tahun.

\section{Jenis Dan Sumber Data}

Jenis data yang digunakan dalam penelitian ini adalah data sekunder. Data sekunder merupakan data yang diperoleh peneliti dari sumber yang sudah ada. Data sekunder didapatkan dari penelitian-penelitian terdahulu dan berbagai literature-literatur yang dapat mendukung penelitian. 
Data sekunder yang digunakan dalam penelitian ini adalah laporan keuangan perusahaan perdagangan besar yang telah diaudit. Yang didapatkan dengan mengakses www.idx.co.id atau dari situs resmi masing-masing perusahaan.

\section{Teknik Pengumpulan Data}

Teknik pengumpulan data yang digunakan dalam penelitian ini yaitu metode dokumentasi dan studi pustaka. Data sekunder dalam penelitian ini diperoleh melalui metode dokumentasi. Metode dokumentasi dilakukan dengan cara mengumpulkan, mencatat dan mengkaji data sekunder yang terdiri dari annual report, laporan keuangan beserta laporan audit oleh auditor independen dari perusahaan sektor keuangan yang listing dan dipublikasikan oleh Bursa Efek Indonesia selama periode penelitian melalui Indonesia Stock Exchange (idx).

\section{Teknik Analisis Data}

Tujuan dari analisis data adalah untuk membuat kesimpulan atau menarik kesimpulan mengenai karakteristik populasi berdasarkan data yang didapatkan dari sampel biasanya ini dibuat berdasarkan pendugaan dan pengujian hipotesis. Metode analisis data penelitian ini menggunakan teknik analisis kuantitatif. Dalam penelitian ini, analisis kuantitatif dilakukan dengan cara mengkuantifikasi data-data penelitian sehingga menghasilkan informasi yang dibutuhkan dalam analisis. Analisis yang digunakan dalam penelitian ini adalah analisis model legit atau regresi logistik (logistik regression) dengan bantuan IBM Statistikal Package for Social Sciences (SPSS) versi 23. Menurut Ghozali (2011) logistik regression sebenarnya mirip dengan analisis diskriminan yaitu menguji apakah probabilitas variabel terikat dapat diprediksi dengan variabel bebasnya. Alasan menggunakan regresi logistik adalah dalam analisis regresi logistik (Iogistic Regression) tidak memerlukan uji asumsi multivariate normal distribution karena variabel bebas merupakan campuran antara variabel kontinyu (metrik) dan kategorial (non-metrik) (Gozali, 2011).

Menurut Winarno (2011) model logit (logistik regression) adalah model regresi yang digunakan untuk menganalisis variabel dependen dengan kemungkinan diantara 0 dan 1 . Tahapan analisis regresi logistik (logistik regression) yaitu dengan pengujian kelayakan model regresi, hipotesis, menilai kelayakan model regresi (goodness of fit test), menilai model fit (overall model fit), uji regresi. Metode analisis data yang digunakan yaitu statistik deskriptif yang digunakan untuk untuk mendeskripsikan data yang telah terkumpul tanpa melakukan generalisasi.

\section{HASIL PENELITIAN DAN PEMBAHASAN}

Penelitian ini menggunakan populasi perusahaan sektor perdagangan besar yang terdaftar di Bursa Efek Indonesia (BEI) selama tahun 2013-2017. Perusahaan sektor perdagangan besar yang telah terdaftar di Bursa Efek Indonesia sebelum 1 Januari 2013 dan tidak dikeluarkan (delisting) selama periode penelitian. Pada penelitian ini metode yang digunakan untuk penentuaan sampel adalah purposive sampling. Penelitian ini mengambil sampel selama 5 tahun, yaitu dari tahun 20132017, juga menggunakan tahun 2012 karena terdapat variabel yang membutuhkan data dari tahun sebelumnya ( $\mathrm{t}-1)$, namun data tahun 2012 tidak dimasukkan dalam 


\section{Jurnal Buana Akuntansi}

analisis statistik karena beberapa data yang dibutuhkan dari tahun tersebut tidak digunakan, data tersebut hanya digunakan untuk melengkapi data tahun 2013. Data yang digunakan yaitu diambil dari laporan keuangan dan annual report pada tahun 2013-2017 yang diakses melalui website wwww.idx.co.id. berikut:

Adapun proses seleksi dari sampel yang didasarkan pada kriteria sebagai

Tabel 1: Tahapan Seleksi Sampel Dan Kriteria

\begin{tabular}{lllc} 
No & Kriteria & Jumlah \\
\hline 1 & $\begin{array}{l}\text { Jumlah seluruh perusahaan sektor perdagangan } \\
\text { besar yang listing di BEI tahun 2013-2017 }\end{array}$ & 37 \\
\hline 2 & $\begin{array}{l}\text { Perusahaan sektor perdagangan besar yang } \\
\text { tidak menerbitkan laporan keuangan, annual }\end{array}$ & (14) \\
& $\begin{array}{l}\text { report beserta laporan audit oleh auditor } \\
\text { independen selama tahun 2013-2017 }\end{array}$ & \\
\hline 3 & $\begin{array}{l}\text { Perusahaan sektor perdagangan besar yang } \\
\text { tidak memiliki data yang lengkap untuk }\end{array}$ & $(3)$ \\
& $\begin{array}{l}\text { mendukung penelitian } \\
4\end{array}$ & $\mathbf{2 0}$ \\
\hline 5 & Jumlah perusahaan sampel & $\mathbf{5}$ \\
\hline 6 & Jumun pengamatan perusahaan sampel selama tahun \\
& pengamatan & &
\end{tabular}

\section{Analisis Statistik Deskriptif}

Analisis statistik deskriptif digunakan untuk mengetahui deskripsi suatu data yang dilihat dari nilai minimum, maksimum, rata-rata, dan standar deviasi berdasarkan variabel spesialisasi auditor, rotasi audit, ukuran kantor akuntan publik, kualitas audit. Berdasarkan analisis statistik deskriptif diperoleh gambaran sampel sebagai berikut:

Tabel 2: Statistik Deskriptif audit tenure, Rotasi Audit, Ukuran Kantor Akuntan 


\section{Jurnal Buana Akuntansi}

\begin{tabular}{|c|c|c|c|c|c|}
\hline & $\mathrm{N}$ & $\begin{array}{l}\text { linimu } \\
\mathrm{m}\end{array}$ & Maximum & Mean & $\begin{array}{c}\text { Std. } \\
\text { Deviation }\end{array}$ \\
\hline $\begin{array}{l}\text { Kualitas } \\
\text { Audit }\end{array}$ & 100 & 0 & 1 & .13 & .338 \\
\hline Audit Tenure & 100 & 1 & 5 & 2.42 & 1.387 \\
\hline Rotasi Audit & 100 & 0 & 1 & .18 & .386 \\
\hline Ukuran Kap & 100 & 0 & 1 & .48 & .502 \\
\hline $\begin{array}{l}\text { Valid N } \\
\text { (Listwise) }\end{array}$ & 100 & & & & \\
\hline
\end{tabular}

\section{Publik, dan Kualitas Audit}

Berdasarkan tabel di atas dapat diketahui bahwa:

Jumlah unit analisis $(\mathrm{N})$ dalam penelitian adalah sebanyak 100 unit analisis yang terdiri dari 20 perusahaan sektor perdagangan besar yang terdaftar di Bursa Efek Indonesia dari tahun 2013-2017.

Variabel dependen berupa kualitas audit $(\mathrm{Y})$ memiliki nilai minimum 0 dan maksimum 1, sedangkan nilai rata-rata sebesar 0.13 dan standar deviasi sebesar 0,338. Nilai terkecil (minimum) diberikan kepada perusahaan yang tidak menerima opini audit going concern sedangkan nilai terbesar (maximum) diberikan kepada perusahaan yang mendapat opini going concern.

Variabel independen yaitu Audit Tenure (X1) memiliki nilai minimum 1 dan nilai maksimum 5.sedangkan nilai rata-rata 2,42 dan standar deviasi 1,387. Nilai minimum menunjukkan masa perikatan sebesar 1 dan nilai maksimum menunjukkan masa perikatan auditor dengan perusahaan sebesar 5 .

Variabel independen berupa Rotasi Audit (X2)pada perusahaan yang menjadi sampel dalam penelitian ini memiliki nilai minimum sebesar 0 dan nilai maksimum sebesar 1, sedangkan nilai rata-rata sebesar 0,18 dengan standar deviasi sebesar 0,386.Nilai terkecil (minimum) diberikan kepada perusahaan yang tidak melakukan rotasi audit sedangkan nilai terbesar (maximum) diberikan kepada perusahaan yang melakukan rotasi audit.

Variabel dependen berupa Ukuran Kantor Akuntan Publik (X3) pada perusahaan yang menjadi sampel dalam penelitian ini memiliki nilai minimum sebesar 0 dan nilai maksimum sebesar 1 , sedangkan nilai rata-rata sebesar 0,48 dengan standar deviasi sebesar 0,502. Nilai terkecil (minimum) diberikan kepada perusahaan yang tidak diaudit oleh KAP Big Four sedangkan nilai terbesar (maximum) diberikan kepada perusahaan yang diaudit oleh KAP Big Four.

\section{Hasil Uji Kesesuaian Keseluruhan Model (Overall Model Fit)}

Berikut ini disajikan data hasil pengujian kesesuaian keseluruhan model (overall model fit) berdasarkan pada fungsi likelihood. 
Tabel 3

Hasil Uji Menilai Keseluruhan Model

\begin{tabular}{|c|c|}
\hline Keterangan & -2 Log Likelihood \\
\hline Block Number : 0 & 77,277 \\
\hline Block Number : 1 & 62,886 \\
\hline
\end{tabular}

Berdasarkan tabel di atas diketahui bahwa pengujian dilakukan dengan membandiingkan nilai -2 log likelihood (-2LL) pada awal (block number 0) dengan nilai -2 Log Likelihood (-2LL) pada akhir (Block Number=1). Nilai -2LL awal adalah sebesar 77,277. Setelah dimasukkan ketiga variabel independen, maka nilai -2LL akhir mengalami penurunan menjadi 62,886. Penurunan Likelihood (-2LL) ini menunjukkan model regresi yang lebih baik atau dengan kata lain model yang dihipotesiskan fit dengan data.

\section{Hasil Uji Koefisien Determinasi ( Nagelkerke R Square) \\ Tabel 4 \\ Hasil Uji Koefisien Determinasi

\begin{tabular}{|l|c|c|c|}
\hline Step & $\begin{array}{c}-2 \text { Log } \\
\text { likelihood }\end{array}$ & $\begin{array}{c}\text { Cox \& Snell } \\
\text { R Square }\end{array}$ & $\begin{array}{c}\text { Nagelkerke } \\
\text { R Square }\end{array}$ \\
\hline 1 & $62.886^{\mathrm{a}}$ & .134 & .249 \\
\hline
\end{tabular}

Berdasarkan tabel 4, nilai statistik Nagelkerke $R$ Square 0,249. Nilai tersebut diinterpretasikan sebagai kemampuan audit tenure, rotasi audit, dan ukuran kantor akuntan publik dalam mempengaruhi kualitas audit sebesar 24,9\%, sisanya $75,1 \%$ dijelaskan oleh variabel-variabel atau faktor-faktor lain seperti fee audit, spesialisasi auditor, ukuran perusahaan klien.

\section{Hasil Uji Kelayakan Model Regresi}

Hasil uji kelayakan model regresi diuji dengan menggunakan Hosmer and Lemeshow Test. Berikut ini disajikan tabel hasil uji kelayakan model regresi:

Tabel 5

Uji Kelayakan Model Regresi

Berdasarkan

\begin{tabular}{|c|c|c|c|}
\hline Step & $\begin{array}{c}\text { Chi- } \\
\text { square }\end{array}$ & Df & Sig. \\
\hline 1 & 3.089 & 7 & .877 \\
\hline
\end{tabular}

menunjukkan bahwa nilai Chi-Square sebesar 3,089 dengan signifikansi (p) sebesar 0,877. Berdasarkan hasil tersebut, karena nilai signifikansi lebih besar dari 0,05 maka model dapat disimpulkan mampu memprediksi nilai observasinya (model dapat dikatakan fit).

\section{Matriks Klasifikasi}

Matriks klasifikasi menunjukkan kekuatan prediksi dari model regresi untuk memprediksi kemungkinan kualitas audit perusahaan dari opini audit 


\section{Jurnal Buana Akuntansi}

going concern dan opini audit non going concern. Hasil uji matriks klasifikasi dapat dilihat pada tabel berikut:

\section{Tabel 6}

Matriks Klasifikasi

Tabel

\begin{tabular}{|l|l|l|l|l|l|}
\hline \multicolumn{2}{|c|}{} & \multicolumn{2}{|l|}{ Predicted } \\
\cline { 4 - 5 } \multicolumn{2}{|c|}{ K_AUServed } & $\begin{array}{l}\text { Kon } \\
\text { Going } \\
\text { Concer } \\
n\end{array}$ & $\begin{array}{l}\text { Going } \\
\text { Concern }\end{array}$ & $\begin{array}{l}\text { Percenta } \\
\text { ge } \\
\text { Correct }\end{array}$ \\
\hline $\begin{array}{l}\text { Step } \\
0\end{array}$ & $\begin{array}{l}\text { K_AU } \\
\text { D }\end{array}$ & $\begin{array}{l}\text { Non } \\
\text { Going } \\
\text { Concern }\end{array}$ & 87 & 0 & 100.0 \\
\hline $\begin{array}{l}\text { Going } \\
\text { Concern }\end{array}$ & 13 & 0 & 0 \\
\cline { 2 - 5 } & Overall percentage & & & 87,0 \\
\hline
\end{tabular}

di atas

menunjukkan bahwa kekuatan dari kualitas audit dapat dilihat pada opini audit non going concern dimana mendapatkan percentage correct sebesar $100 \%$ hal ini menunjukkan model regresi yang digunakan ada sebanyak 87 laporan keuangan $(100 \%)$ yang diprediksi akan melihat kualitas audit dengan opini audit non going concern. Kekuatan prediksi model perusahaan yang melihat kualitas audit dengan going concern adalah $0 \%$ yang berarti bahwa model regresi yang digunakan tidak ada perusahaan yang diprediksi akan melihat kualitas audit dengan opini audit going concern dari total 13 laporan keuangan yang melihat dengan opini audit going concern.

\section{Hasil Uji Regresi Logistik}

Model regresi logistik yang terbentuk disajikan pada tabel di bawah ini:

Tabel 7

Hasil Uji Koefisien Regresi Logistik

\begin{tabular}{|ll|r|r|r|r|r|r|}
\hline & & \multicolumn{1}{|c|}{ B } & \multicolumn{1}{c|}{ S.E. } & Wald & df & Sig. & $\operatorname{Exp}(\mathrm{B})$ \\
\hline Step & X1 & -.843 & .423 & 3.970 & 1 & .046 & .431 \\
$1^{\mathrm{a}}$ & X2 & .213 & .733 & .085 & 1 & .771 & 1.238 \\
& X3 & - & .842 & 2.537 & 1 & .111 & .262 \\
& 1.341 & & & & & \\
& Consta & .033 & .825 & .002 & 1 & .968 & 1.034 \\
nt & & &
\end{tabular}

Hasil pengujian terhadap koefisien regresi logistik menghasilkan model berikut ini:

$\operatorname{Ln}(p / 1-p)=K \_A U D=0,033-0,843 X_{1}+0,213 X_{2}-1,341 X_{3}+e$ 
Berdasarkan tabel di atas menunjukan bahwa variabel independen yaitu audit tenure memiliki koefisien negatif sebesar -0.843 dengan tingkat signifikansi 0,046 . Karena tingkat signifikansi (p) lebih kecil dari $a=5 \%$ maka hipotesis satu $\left(\mathrm{H}_{1}\right)$ diterima yang artinya audit tenure berpengaruh negatif terhadap kualitas audit.

Variabel rotasi audit sebagai variabel independen memiliki koefisien sebesar 0.213 dengan tingkat signifikansi 0,771. Karena tingkat signifikansi (p) lebih besar dari $a=5 \%$ maka hipotesis kedua $\left(\mathrm{H}_{2}\right)$ tidak diterima yang artinya rotasi audit tidak berpengaruh terhadap kualitas audit.

Variabel ukuran KAP sebagai variabel independen memiliki koefisen negatif sebesar -1.341 dengan tingkat signifikan 0,111. Karena tingkat signifikansinya lebih besar dari $a=5 \%$, hal ini berarti bahwa ukuran kantor akuntan publik tidak berpengaruh terhadap kualitas audit maka hipotesis ketiga atau $\left(\mathrm{H}_{3}\right)$ ditolak.

\section{Pembahasan}

Hasil pengujian hipotesis yang dikembangkan dalam penelitian ini secara ringkas disajikan sebagai berikut:

\section{Tabel 8}

Hasil Pengujian Hipotesis

\begin{tabular}{|c|l|c|}
\hline Hipotesis & \multicolumn{1}{|c|}{ Pernyataan } & Hasil \\
\hline $\mathrm{H}_{1}$ & $\begin{array}{l}\text { Audit tenure } \\
\text { berpengaruh negatif } \\
\text { dan signifikan } \\
\text { terhadap kualitas audit }\end{array}$ & $\begin{array}{c}\text { Hipotesis } \\
\text { diterima }\end{array}$ \\
\hline $\mathrm{H}_{2}$ & $\begin{array}{l}\text { Rotasi audit tidak } \\
\text { berpengaruh terhadap } \\
\text { kualitas audit }\end{array}$ & $\begin{array}{c}\text { Hipotesis } \\
\text { ditolak }\end{array}$ \\
\hline $\mathrm{H}_{3}$ & $\begin{array}{l}\text { Ukuran kantor } \\
\text { akuntan publik tidak } \\
\text { berpengaruh terhadap } \\
\text { kualitas audit }\end{array}$ & $\begin{array}{c}\text { Hipotesis } \\
\text { ditolak }\end{array}$ \\
\hline
\end{tabular}

\section{Pengaruh Antara Audit Tenure Dengan Kualitas Audit}

Hasil uji koefisien regresi logistik menunjukkan bahwa audit tenure memiliki koefisien negatif sebesar -0,843 dengan tingkat signifikansi yang dimiliki oleh variabel audit tenure sebesar 0,046. Nilai signifikansi tersebut lebih kecil dari 0,05. Hal ini berarti bahwa audit tenure berpengaruh negatif dan signifikan terhadap kualitas audit. Dengan demikian dapat disimpulkan bahwa penelitian ini menerima $\mathrm{H}_{1}$.

Penelitian ini sesuai dengan penelitian yang dilakukan oleh Giri (2010) yang membuktikan bahwa variabel audit tenure berpengaruh negatif dan signifikan terhadap kualitas audit, didukung juga oleh penelitian Panjaitan (2014) yang menyatakan bahwa audit tenure berpengaruh negatif terhadap kualitas audit yang artinya semakin lama perikatan KAP dengan klien maka akan memiliki kualitas audit yang lebih rendah. Hal ini disebakan tenure biasanya dikaitkan dengan pengaruhnya terhadap independensi auditor. Hubungan yang panjang antara KAP dan klien 
berpotensi untuk menimbulkan kedekatan antara mereka, hal tersebut dapat menghalangi independensi auditor dan mengurangi kualitas audit (Al-Thuneibat et al., 2011). Juga didukung oleh penelitian Nurintianti dan Purwanto (2017) bahwa audit tenure berpengaruh negatif terhadap kualitas audit. Hal ini juga menyebabkan audit tenure yang berlangsung lama membuat auditor kehilangan sikap profesionalismenya sehingga menjalankan proses audit berada dibawah pengaruh manajemen sehingga jika terdapat kesalahan dari perusahaan maka sulit untuk auditor mempublikasikannya karena auditor menganggap bisa saja perusahaan memutuskan kontrak dalam mengaudit laporan keuangan klien sehingga akan kehilangan pekerjaan. Dengan lamanya masa perikatan yang terjalin antara auditor dan perusahaan maka akan berdampak pada menurunnya kualitas audit hal ini disebabkan karena auditor telah memiliki hubungan emosional yang erat sehingga terjalin keakraban yang memungkinkan menurunnya independensi auditor sehingga berbagai kecurangan perusahaan dapat dimanipulasi oleh auditor sehingga kualitas audit yang dihasilkan dapat menurunkan kepercayaan pengguna laporan keuangan. Juga dengan singkatnya masa perikatan auditor dengan klien akan berakibat pada kurang efektifnya auditor dalam melaksanakan prosedur audit yang baik sehingga memungkinkan melewati beberapa prosedur audit yang telah direncankan sehingga kualitas audit menjadi rendah juga dengan singkatnya masa perikatan akan menyulitkan auditor untuk memahami dan mendeteksi setiap kesalahan atau penyimpangan yang dilakukan oleh auditor.

\section{Pengaruh Rotasi Audit Terhadap Kualitas Audit}

Variabel rotasi audit sebagai variabel independen memiliki koefisien positif sebesar 0,213 dengan signifikansi terhadap kualitas audit sebesar 0,771. Nilai signifikansi tersebut lebih besar dari 0,05. Hal ini berarti bahwa rotasi audit tidak memiliki pengaruh yang signifikan terhadap kualitas audit. Dengan demikian dapat disimpulkan bahwa penelitian ini menolak $\mathrm{H}_{2}$

Penelitian ini sejalan dengan penelitian Hartadi (2012) yang menyatakan bahwa rotasi audit tidak berpengaruh terhadap kualitas audit. Hal ini disebabkan karena pasar sebenarnya tidak terlalu peduli apakah auditor yang menyatakan opini pada laporan keuangan tahunan tersebut pernah dirotasi atau tidak. Hasil penelitian ini mendukung penelitian Ramdani (2017) yang menyatakan bahwa rotasi audit tidak berpengaruh terhadap kualitas audit sebab kurangnya kepedulian pelaku pasar terhadap pergantian auditor dan tim auditnya masih baru sehingga pengalaman auditnya masih baru. Juga sejalan dengan penelitian yang dilakukan Sofyana dan Nugroho (2012) variabel rotasi audit tidak berpengaruh terhadap kualitas audit dikarenakan independensi auditor, biaya yang cukup besar, waktu yang cukup lama untuk KAP untuk mempelajari alur bisnis perusahaan dan juga perusahaan takut akan terungkapnya semua kecurangan yang ada dan perusahaan memiliki pengalaman terhadap KAP lain yang kinerjanya tidak memuaskan. Hal ini juga disebabkan karena tingginya profesionalisme auditor tersebut yang bersikap independen dalam melaksanakan audit, sehingga baik dilakukan rotasi audit atau 
tidak jika seorang auditor menjunjung tinggi independensi maka tidak akan terpengaruh oleh hal-hal yang dapat mengurangi kualitas audit . Rotasi audit tidak mempengaruhi kualitas audit juga disebabkan karena perusahaan menganggap bahwa semua auditor akan berusaha semaksimal mungkin untuk memeriksa dan memberikan opini sesuai dengan keadaan dari perusahaan karena klien merasa bahwa baik sering mengganti auditor maupun lama akan sama karena semua auditor menginginkan reputasi yang baik. Tetapi untuk menghindari hal-hal yang tidak diinginkan maka terdapat dua alasan dalam melaksanakan rotasi audit yaitu mandatory dan voluntary.

\section{Pengaruh Ukuran Kantor Akuntan Publik Terhadap Kualitas Audit}

Variabel ukuran KAP sebagai variabel independen memiliki koefisen negatif sebesar -1.341 dengan tingkat signifikansi 0,111. Nilai signifikansi tersebut lebih besar dari 0,05. Hal ini berarti bahwa ukuran kantor akuntan publik yang dinyatakan dalam KAP big four dan KAP non big four tidak memiliki pengaruh yang signifikan terhadap kualitas audit. Dengan demikian dapat disimpulkan bahwa $\mathrm{H}_{3}$ ditolak.

Hasil penelitian ini sesuai dengan penelitian yang dilakukan oleh Panjaitan dan Chariri (2014); ukuran kantor akuntan publik tidak berpengaruh terhadap kualitas audit atas pemeriksaan laporan keuangan pada perusahaan-perusahaan. Kantor akuntan publik yang berafiliasi dengan KAP Big four tidak cenderung menghasilkan kualitas audit yang lebih baik dari pada KAP yang tidak berafiliasi dengan KAP Big four. Dari hasil penelitian dari Siregar dan Nindita, diperoleh beberapa kesimpulan bahwa ukuran KAP tidak berpengaruh signifikan terhadap kualitas audit yang diukur dengan nilai akrual dan ukuran KAP juga tidak memiliki pengaruh terhadap probabilita penerbitan laporan audit going concern. Artinya bahwa tidak terdapat perbedaan kualitas akrual bagi perusahaan yang diaudit oleh KAP yang besar, baik itu KAP Big Four maupun KAP Non Big Four. Selain itu, penerbitan laporan audit going concern pada perusahaan yang diaudit oleh KAP yang besar juga dapat dikatakan seragam dengan KAP yang kecil. Secara keseluruhan disimpulkan bahwa hasil pengujian belum dapat memberi bukti yang konsisten dengan penelitian sebelumnya. Pengujian sensitifitas atas pengukuran ukuran KAP juga belum memberikan bukti bahwa KAP yang lebih besar akan menghasilkan kualitas audit yang lebih baik. Hal ini kemungkinan besar terjadi karena terdapat faktor-faktor yang lebih mempengaruhi kualitas audit selain faktor ukuran KAP. Faktor tersebut adalah kompetensi dan independensi. Apabila ukuran KAP yang besar tidak dibarengi dengan kompetensi yang tinggi dari auditornya, kemampuan mendeteksi manajemen laba serta kesangsian kelangsungan usaha pun akan rendah. Nindita: Pengaruh Ukuran Kantor Akuntan Publik Terhadap Kualitas Audit 103 Akibatnya kualitas akrual juga akan rendah. Begitu juga dengan independensi, KAP dengan ukuran besar yang auditornya memiliki kompetensi yang tinggi akan membantu perusahaan dalam melakukan manajemen laba apabila auditor tersebut kurang memiliki independensi.

Selain itu untuk bertahan dalam persaingan bisnis, kantor akuntan publik baik big four maupun non big four akan berusaha semaksimal mungkin untuk 


\section{Jurnal Buana Akuntansi}

memepertahankan eksistensinya dalam bisnis jasa akuntan publik sehingga mereka akan bekerja sesuai dengan prosedur audit yang baik untuk menghasilkan laporan audit yang berkualitas sehingga mendapatkan kepercayaan dari klien.

\section{KESIMPULAN DAN SARAN \\ Kesimpulan}

Penelitian ini dilakukan untuk mengetahui pengaruh audit tenure, rotasi audit, dan ukuran kantor akuntan publik terhadap kualitas audit. Penelitian ini menggunakan perusahaan sektor perdagangan besar yang terdaftar di Bursa Efek Indonesia periode 2013-2017 sebagai populasi penelitian yaitu 37 perusahaan sektor perdagangan besar dan 20 perusahaan yang memenuhi kriteria menjadi sampel penelitian.

Berdasarkan hasil penelitian ini, terdapat beberapa hal yang dapat disimpulkan antara lain:

1 Hasil uji regresi logistik (logistic regression) menunjukkan bahwa audit tenure berpengaruh negatif dan signifikan terhadap kualitas audit. Hasil penelitian ini mendukung dari penelitian dari hasil penelitian yang dilakukan oleh Giri (2010), Panjaitan (2014), Nurintiati dan Purwanto (2018).

2 Hasil uji regresi logistik (logistic regression) menunjukkan bahwa rotasi audit tidak berpengaruh terhadap kualitas audit. Hasil penelitian ini didukung dari hasil penelitian yang dilakukan oleh Hartadi (2012), Ramdani (2017), Sofyana dan Nugroho (2012)

3 Hasil uji regresi logistic (logistic regression) menunjukkan bahwa ukuran kantor akuntan publik tidak berpengaruh terhadap kualitas audit, penelitian ini didukung dari hasil penelitian yang dilakukan oleh Panjaitan dan Chariri (2014).

\section{Saran}

Beberapa saran yang dapat dipertimbangkan untuk peneliti selanjutnya yang melakukan penelitian berkaitan dengan kualitas audit:

1 Bagi peneliti selanjutnya disarankan menambah variabel lain yang berkaitan erat secara teori terhadap variabel kualitas auditserta memperluas ruang lingkup penelitian, agar hasil penelitian dapat diperluas. Hal ini dimaksudkan agar hasil penentuan kualitas audit lebih baik.

2 Penelitian ini hanya menggunakan sampel perusahaan sector perdagangan besar. Peneliti selanjutnya dapat mempertimbangkan untuk memperluas sampel penelitian dengan menggunakan sampel perusahaan dari seluruh sektor terdaftar di BEI 


\section{Jurnal Buana Akuntansi}

\section{DAFTAR PUSTAKA}

Al-Thuneibat, Ibrahim Isa, dan Ata Baker, 2011. “Do Audit tenure and Firm Size Contribute to Audit Quality?" Journal of Accounting and Economics, Jordan.

Atmaja, Lukas Setia. 2008. Teori dan Praktik Manajemen Keuangan. Yogyakkarta: Penerbit Andi.

Efraim, F. 2010. “Pengaruh Tenur KAP dan Reputasi KAP Terhadap Kualitas Audit: Kasus Rotasi Wajib Auditor di Indonesia". Simposium Nasional Akuntansi XIII Purwokerto

Giri, E. F.(2010). Pengaruh Tenur Kantor Akuntan Publik (KAP) dan Reputasi KAP terhadap Kualitas Audit : Kasus Rotasi Wajib Auditor di Indonesia. Simposium Nasional Akuntansi XIII Purwokerto,13-15 Oktober:1-26.

Halim, Abdul. "Auditing (Dasar-Dasar Audit Laporan Keuangan)", Jilid 1, UPP STIM YKPN, Yogyakarta, 2008.

Hamid, Abdul. "Pengaruh Tenur KAP dan Ukuran KAP terhadap Kualitas Audit", Fakultas Ekonomi Universitas Negeri Padang, 2013.

Hartadi, Bambang. "Pengaruh Fee Audit, Rotasi KAP, dan Reputasi Auditor terhadap Kualitas Audit di Bursa Efek Indonesia", Jurnal Ekonomi dan Keuangan, Vol 16, No. 1, hal 84-103, 2012.

Hasbi, A.R.A. (2018). “Pengaruh Audit Tenure, Auditor Switching, Dan Company Size Terhadap Kualitas Audit Pada Perusahaan Manufaktur Yang Terdaftar Di Bursa Efek Indonesia Tahun 2012-2015”. (Skripsi). Universitas Islam Negeri Alauiddin Makassar.

Himawan, Ferdinandus. A dan Rara Emarila. "Pengaruh Persepsi Auditor atas Kompetensi, Independensi dan Kualitas Audit terhadap Umur Kantor Akuntan Publik (KAP) Di Jakarta", Esensi Volume 13 No. 3, Jakarta, Desember, 2013

Hutabarat, G. (2012). Pengaruh Pengalaman Time Budget Pressure dan Etika 6034.

Jensen, M.C., \& Meckling, W.H.(1976).Theory of the Firm: Managerial Behavior Agency Cost, and Ownership Structure. Journal of Finance Economics, 3, 305-360. Diakses dari https:// papers.ssrn.com.

Kurniasih, Margi. (2014). Pengaruh Fee Audit, Audit Tenure, Dan Rotasi Audit Terhadap Kualitas Audit (Studi Empiris pada Perusahaan Manufaktur Go 


\section{Jurnal Buana Akuntansi}

Public yang Terdaftar di Bursa Efek Indonesia tahun 2008-2012). (skripsi). Universitas diponegoro.

Kurniasih, M,\& Rohman, A. (2014). Pengaruh Fee Audit, Audit Tenure, dan Rotasi Audit Terhadap Kualitas Audit. Diponegoro Journal of Accounting. Diakses dari eprints.undip.ac.id.

Mayasari, Ida. "Pengaruh Profesionalisme Auditor dan Masa Perikatan Audit Terhadap Kualitas Audit", Universitas Komputer Indonesia, Bandung, 2013.

Mgbame, C.O., Eragbhe, E dan Osazuwa, N, "Audit Partner Tenure and Audit Quality: An Emprical Analysis", European Journal of Business and Management, Vol. 4, No. 7, pp.154-159, 2012.

Mulyadi (2010). Auditing (Edisi 6). Jakarta: Salemba Empat.

Nuratama, I Putu. "Pengaruh Tenur dan Reputasi Kantor Akuntan Publik Pada Kualitas Audit dengan Komite Audit Sebagai Variabel Moderasi", Denpasar,2011.

Nurintiati,A.A., \& Purwanto, A, "Pengaruh Tenure Kap, Ukuran Kap, Spesialisasi Auditor Dan Audit Fee Terhadap Kualitas Audit Dengan Moderasi Komite Audit", jurnal ilmiah akuntansi,Vol 6,No.1, pp 1-13, 2017

Panjaitan,C.M.dan Chariri, A.,(2014)."Pengaruh Tenure, Ukuran KAP Dan Spesialisasi Auditor", jurnal ilmiah akuntansi, Vol.3, No.3, pp. 1-12, 2014.

Putra, I Gede Cahyadi. "Kualitas Audit Kantor Akuntan Publik di Bali Ditinjau dari Time Budget Pressure Risiko Kesalahan, dan Kompleksitas Audit", Jurnal Ilmiah Akuntansi dan Humanika Jinah, Vol.2, No.2,pp. 765-784, 2013.

Perdana, M. Hadi, (2014). Pengaruh Rotasi Kantor Akuntan Publik dan Rotasi Akuntan Publik (Partner Auditor) Terhadap Kualitas Audit. Skripsi, Universitas Diponegoro.

Putri, T.M. (2014). Pengaruh Auditor Tenure, Ukuran Kantor Akuntan Publik, dan Ukuran Perusahaan Klien terhadap Kualitas Audit (Studi Empiris pada Perusahaan Maufaktur yang Terdaftar di BEI pada Tahun 2010-2012) (Skripsi). Universitas Diponegoro, Semarang.

Radona, Bani, (2017). Analisis Pengaruh Audite Tenure, Audit Fee, Audit Switching, Ukuran Perusahaan Dan Independensi Audit Terhadap Kualitas Audit. Skripsi. Universitas Sumatera Utara 


\section{Jurnal Buana Akuntansi}

Ramdani, Rifky. (2016). Pengaruh Fee Audit, Audit Tenure, Rotasi Audit Dan Ukuran Perusahaan Klien Terhadap Kualitas Audit pada Sektor Keuangan yang Terdaftar di BEI Periode 2012-2014. (Skripsi). Universitas Islam Negeri Jakarta

Simangunsong, C. (2015). Faktor - Faktor yang Mempengaruhi Penerimaan Opini Audit Going Concern pada Perusahaan Perbankan yang Terdaftar di Bursa Efek Indonesia Tahun 2010 - 2012(Skripsi). Universitas Sumatera Utara. Medan

Simanjuntak, Piter. (2008). Pengaruh Time Budget Pressure dan Resiko Kesalahan terhadap Penurunan Kualitas Audit. Tesis. Universitas Diponegoro Semarang.

Siregar, B.U. (2016). Pengaruh Audit Tenure, Reputasi Auditor, Spesialisasi Audit, dan Ukuran Perusahaan terhadap Kualitas Audit Pada Perusahaan Property dan Real Estate yang terdaftar di Bursa Efek Indonesia (BEI)(Skripsi). Universitas Sumatera Utara. Medan

Sopian, Dani. 2014. Pengaruh Ukuran Kantor Akuntan Publik dan Masa Perikatan Audit terhadap Kualitas Audit serta Implikasinya Terhadap Kualitas Laba. Jurnal Sains Manajemen \& Akuntansi. Vol VI, No 1. Standar Profesional Akuntan Publik.2013.

Sofyana dan Gatot, "Analisis Pengaruh Praktik Rotasi Audit dan Masa Pemberian Jasa Audit terhadap Kualitas Audit", 2012. 